\title{
IMPLEMENTASI KEBIJAKAN PEMERINTAH DAERAH TENTANG PENYELENGGARAAN KETENAGAKERJAAN DALAM PROGRAM BADAN PENYELENGGARA JAMINAN SOSIAL (BPJS) DI KOTA CIMAHI
}

\author{
Tiara Friskadewi ${ }^{1}$ \\ 1Jurusan Ilmu Pemerintahan, Fakultas Ilmu Sosial dan Ilmu Politik, Universitas \\ Jenderal Achmad Yani
}

\begin{abstract}
Abstrak
Judul penelitian "Kebijakan Pemerintah Daerah tentang Penyelenggaraan Ketenagakerjaan Dalam Program Badan Penyelenggara Jaminan Sosial (BPJS) di Kota Cimahi". Masalah penelitian belum optimanya Kebijakan Pemerintah Daerah tentang Penyelenggaraan Ketenagakerjaan Dalam Program BPJS di Kota Cimahi dilihat dari masih banyak tenaga kerja yang belum mendaftar BPJS di Kota Cimahi. Adapun identifikasi masalah Bagaimana Kebijakan Pemerintah Daerah tentang Penyelenggaraan Ketenagakerjaan Dalam Program BPJS di Kota Cimahi. Tujuan penelitian untuk mendeskripsikan dan menganalisis Kebijakan Pemerintah Daerah tentang Penyelenggaraan Ketenagakerjaan Dalam Program BPJS di Kota Cimahi. Metode penelitian yang digunakan metode deskriptif dengan pendekatan kualitatif. Teknik pengumpulan data melalui studi pustaka dan studi lapangan data (observasi dan wawancara). Teknik analisis data dimulai dari reduksi data, penyajian data dan pada tahap akhir dengan menarik kesimpulan. Teknik pengambilan sampel dilakukan secara purposif. Hasil Penelitian ini menunjukkan bahwa Implementasi Kebijakan Pemerintah Daerah tentang penyelenggaraan ketenagakerjaan di Kota Cimahi sudah optimal. Hal ini dapat dilihat dari dimensi berikut; (1) ukuran dan tujuan kebijakan yang cukup jelas, (2) komunikasi antar pelaksana kebijakan yang sudah terjalin dengan baik, (3) karakteristik badan pelaksana yang cukup tegas dan baik dalam pengelolaan data target kebijakan, (4) Lingkungan sosial ekonomi yang sudah sesuai. Akan tetapi ada beberapa hal yang masih belum optimal. Hal ini dikarenakan, dari segi kualitas sumber daya manusia sudah baik, namun kuantitas sumber daya yang ada perlu ditambah agar pelaksanaan kebijakan tentang penyelenggaraan ketenagakerjaan dalam program BPJS dapat berjalan dengan lebih efektif karena kuantitas sumber daya yang ada belum sebanding dengan banyaknya perusahaan di Kota Cimahi yang harus ditangani Kemudian masih kurangnya akuntabilitas dan responsibilitas pemerintah terhadap sasaran kebijakan yakni pihak perusahaan yang merasa terbebani oleh iuran BPJS yang harus dibayarkan untuk tenagakerjanya.
\end{abstract}

Kata Kunci: Implementasi Kebijakan, Tenaga Kerja, BPJS.

\begin{abstract}
The research title is "Local Government Policies on Manpower Implementation in the Social Security Administering Body (BPJS) Program in Cimahi City". The research problem is not yet optimistic of the Regional Government Policy on Manpower Implementation in the BPJS Program in Cimahi City, seen from the many workers who have not registered for BPJS in Cimahi City. The identification of the problem of How Local Government Policies on Manpower Implementation in the BPJS Program in Cimahi City. The purpose of this research is to describe and analyze the Local
\end{abstract}


Government Policies on Manpower Implementation in the BPJS Program in Cimahi City. The research method used is descriptive method with a qualitative approach. Data collection techniques through library research and data field studies (observation and interviews). The data analysis technique starts from data reduction, data presentation and at the final stage by drawing conclusions. The sampling technique was done purposively. The results of this study indicate that the implementation of local government policies on the implementation of manpower in Cimahi City has been optimal. This can be seen from the following dimensions; (1) fairly clear policy size and objectives, (2) well-established communication between policy implementers, (3) fairly firm and good characteristics of implementing agencies in managing policy target data, (4) an appropriate socio-economic environment. However, there are some things that are still not optimal. This is because, in terms of the quality of human resources, it is good, but the quantity of existing resources needs to be increased so that the implementation of policies regarding the implementation of manpower in the BPJS program can run more effectively because the quantity of available resources is not comparable to the number of companies in Cimahi City which must be handled Then there is still a lack of accountability and government responsibility towards policy targets, namely the company that feels burdened by the BPJS fees that must be paid for its employees.

Keywords: Policy Implementation, Manpower, BPJS.

\section{PENDAHULUAN}

Setiap Pemerintah Daerah diberi kewenangan untuk mengurusi daerahnya sendiri. Dalam hal ini Pemerintah Daerah yang dimaksud oleh peneliti adalah wilayah Kabupaten/Kota sebagai pelaksana asas desentralisasi mempunyai urusan wajibyang tidak berkaitan dengan Pelayanan Dasar yang menjadi kewenangan Pemerintah Daerah yang diatur dalam Undang-Undang No 23 Tahun 2014 tentang Pemerintahan Daerah, dalam Pasal 12 ayat (2) disebutkan:

a. Tenaga kerja;

b. Pemberdayaan perempuan dan pelindungan anak;

c. Pangan;

d. Pertanahan;

e. Lingkungan hidup;

f. Administrasi kependudukan dan pencatatan sipil;

g. Pemberdayaan masyarakat dan desa;

h. Pengendalian penduduk dan keluarga berencana;

i. Perhubungan;

j. Komunikasi dan informatika;

k. Koperasi, usaha kecil, dan menengah;

1. Penanaman - penanaman modal;

m. Kepemudaan dan olah raga;

n. Statistik;

n. Persandian; 

o. Kebudayaan;
p. Perpustakaan; dan
q. Kearsipan.

Salah satu dari beberapa hal yang menjadi urusan Pemerintah Daerah tersebut, yang peneliti kaji dalam penelitian ini adalah berkenaan dengan tenaga kerja. Ketenagakerjaan merupakan salah satu penggerak tata kehidupan ekonomi dan merupakan sumber daya yang jumlahnya cukup melimpah. Tenaga kerja mempunyai perananan dan kedudukan yang sangat penting sebagai pelaku dan sasaran pembangunan nasional. Tenaga kerja mempunyai hak-hak yang diatur dalam Undang-Undang No 13 Tahun 2003 tentang Ketenagakerjaan, yang didalamnya termasuk perlindungan tenaga kerja merupakan hal yang harus diperjuangkan agar harkat dan kemanusian tenaga kerja ikut terangkat. Perlindungan tenaga kerja dimaksudkan untuk menjamin hak-hak dasar tenaga kerja dengan tetap memperhatikan perkembangan kemajuan dunia usaha nasional dan internasional.

Kota Cimahi merupakan salah satu kawasan industri di Jawa Barat karena sebagian lahan di Kota Cimahi terutama di bagian Selatan digunakan sebagai kawasan industri. Kawasan ini sudah disusun rapi dan diatur oleh pemerintah, meskipun sebagian kawasan itu berada di sekitar pemukiman warga. Kebanyakan warga yang tinggal di sekitar kawasan itu adalah pekerja di perusahaan tekstil-tekstil tersebut. Selain itu, Kota Cimahi menjadi salah satu tujuan urbanisasi di Jawa Barat karena memiliki daya tarik tersendiri bagi para pendatang dari luar kota untuk besaing mengadu nasib mencari mata pencaharian terutama di sektor wiraswasta dan industri. Dengan adanya urbanisasi tersebut ditambah dengan penduduk asli Kota Cimahi, maka tenaga kerja di Kota Cimahi memiliki jumlah yang cukup besar. Adapun jumlah perusahaan dan tenaga kerja yang ada di Kota Cimahi pada bulan Juli sampai dengan bulan Desember 2016, yaitu: 
Tabel 1

Jumlah Perusahaan Di Kota Cimahi Tahun 2016

\begin{tabular}{|c|c|c|}
\hline Bulan & Jumlah Perusahaan & Jumlah Tenaga Kerja \\
\hline Juli & 593 & 83.085 \\
\hline Agustus & 595 & 83.168 \\
\hline September & 606 & 82.780 \\
\hline Oktober & 591 & 82.062 \\
\hline November & 592 & 82.296 \\
\hline Desember & 593 & \\
\hline
\end{tabular}

Sumber: Dokumen Dinas Tenaga Kerja, Transmigrasi dan Sosial Kota Cimahi

Berdasarkan tabel 1 dapat dilihat bahwa dalam satu tahun pun setiap bulannya terjadi peningkatan jumlah perusahaan maupun jumlah tenaga kerja. Akan tetapi pada bulan oktober mengalami penurunan yakni 15 perusahaan berhenti beroprasi. Dari penelitian awal yang dilakukan oleh peneliti, hal tersebut terjadi karena adanya perusahaan yang mengalami kerugian yang disebabkan oleh kurangnya daya beli konsumen yang mengakibatkan kurangnya pendapatan perusahaan sehingga perusahaan tidak mampu lagi untuk menggaji tenaga kerjanya. Selain itu, banyak perusahaan yang merasa keberatan untuk membayar gaji tenaga kerja Indonesia yang dirasa cukup mahal sehingga ada perusahaan yang hengkang ke negara lain salah satunya adalah Vietnam karena gaji tenaga kerja di Vietnam lebih murah dibandingkan Indonesia termasuk Kota Cimahi.

Salah satu dari beberapa hal-hal yang tercantum dalam Peraturan Daerah tersebut, yang akan peneliti kaji adalah mengenai jaminan sosial bagi tenaga kerja. Jaminan sosial merupakan salah satu bentuk perlindungan sosial untuk menjamin seluruh rakyat agar dapat memenuhi kebutuhan dasar hidupnya yang layak. Jaminan sosial tersebut bertujuan untuk memberikan perlindungan yang bersifat dasar bagi tenaga kerja yang 
bertujuan untuk menjamin adanya keamanan dan kepastian terhadap resiko-resiko sosial ekonomi, dan merupakan sarana penjamin arus penerimaan penghasilan bagi tenaga kerja dan keluarganya akibat dari terjadinya resiko-resiko sosial dengan pembiayaan yang terjangkau oleh pengusaha dan tenaga kerja. Pada hakikatnya jaminan sosial merupakan kebutuhan masyarakat yang mendasar karena menyangkut kelangsungan hidup baik bagi pekerja maupun keluarganya, namun demikian diakui bahwa jaminan sosial bagi tenaga kerja saat ini merupakan kebutuhan yang memperoleh prioritas bagi tenaga kerja yang pelaksanaannya masih belum berjalan seperti yang diharapkan.

BPJS memberikan jaminan sosial terhadap masyarakat dengan tarif iuran yang murah dibandingkan jaminan sosial yang diberikan oleh badan jaminan sosial lainnya sehingga tidak membebankan masyarakat dalam membayar iuran bulanannya. Tarif yang perlu dibayar peserta BPJS setiap bulannya yaitu sekitar Rp. 30.000 sampai dengan Rp. 80.000 sesuai kelas yang dipilih oleh masyarakat, berbeda dengan jaminan sosial yang diberikan oleh pihak swasta yaitu mulai dari Rp. 350.000/bulan. BPJS juga memberikan layanan mengenai semua hal yang menjadi kendala kesehatan semua anggotanya. Misalnya BPJS akan memproteksi biaya gigi, kehamilan, mata, imunisasi dan program keluarga berencana yang tidak dilaksanakan oleh badan jaminan sosial lainnya. Walaupun tidak semua fasilitas kesehatan diberikan oleh BPJS seperti Ruang kelas VIP di Rumah Sakit, Akan tetapi sedikitnya BPJS membantu beban biaya yang harus dikeluarkan, cukup dengan membayar selisih biaya dari iuran kelas BPJS yang dibayar oleh masyarakat setiap bulannya.

Melihat manfaat yang dihasilkan dari program BPJS dan beriringan dengan terselenggaranya proses penjaminan sosial bagi tenaga kerja untuk menjamin hak perlindungan sosial tenaga kerja di Kota Cimahi serta untuk menjalankan kewajiban perusahaan agar mengikutsertakan tenaga kerjanya menjadi peserta BPJS, Pemerintah Daerah membuat suatu kebijakan untuk memewajibkan seluruh perusahaan yang ada di Kota Cimahi untuk mendaftarkan diri dan tenaga kerjanya menjadi peserta jaminan sosial. Hal tersebut ditegaskan dalam Peraturan Daerah Nomor 8 Tahun 2015 Pasal 35 
ayat (1) bahwa: "Setiap orang yang bekerja di wilayah Kota Cimahi, termasuk Orang Asing yang bekerja paling singkat 6 (enam) bulan wajib menjadi peserta Jaminan Sosial”.

Di Kota Cimahi masih banyak perusahaan yang tidak mendaftarkan dirinya dan seluruh tenaga kerjanya untuk menjadi peserta BPJS padahal dalam Peraturan Daerah Kota Cimahi jelas disebutkan bahwa diwajibkan bagi para pemberi kerja untuk mendaftarkan dirinya dan tenaga kerjanya menjadi Peserta BPJS. Adapun jumlah perusahaan dan tenaga kerja yang menjadi peserta BPJS di Kota Cimahi, sebagai berikut:

Tabel 2

Data Perusahaan yang sudah dan belum mendaftar BPJS Tahun 2016

\begin{tabular}{|c|r|c|c|}
\hline Bulan & $\begin{array}{c}\text { Perusahaan yang } \\
\text { mendaftar BPJS }\end{array}$ & $\begin{array}{c}\text { Perusahaan yang } \\
\text { belum mendaftar } \\
\text { BPJS }\end{array}$ & Jumlah \\
perusahaan \\
\hline Juli & 471 & 122 & 593 \\
\hline Agustus & 466 & 129 & 596 \\
\hline September & 477 & 129 & 596 \\
\hline Oktober & 468 & 123 & 592 \\
\hline November & 469 & 123 & 593 \\
\hline Desember & 470 & 123 & \\
\hline
\end{tabular}

Sumber: Dokumen Dinas Tenaga Kerja, Transmigrasi dan Sosial

Kota Cimahi dari tabel 2 jelas terlihat bahwa masih ada sekitar 20\% perusahaan yang belum mendaftarkan tenaga kerjanya sebagai peserta BPJS. Hal tersebut dikarenakan perusahaan tidak bisa mendaftarkan pekerjanya karena perekonomian belum stabil dan persaingan usaha yang cukup tinggi sehingga mengurangi pendapatan, kemudian iuran BPJS menjadi beban seiring dengan tuntutan tenaga kerja yang selalu meminta agar jumlah upah terus ditingkatkan. Selain itu, ada perusahaan yang tidak menjadi peserta BPJS karena memilih asuransi lain dan kepercayaan 
menjadi alasannya, melihat pelayanan BPJS yang masih terbilang buruk. Pasalnya peserta BPJS harus meminta rujukan dari fasilitas kesehatan tingkat satu misalnya puskesmas untuk bisa berobat ke rumah sakit, dan tidak semua rumah sakit menerimanya karena hanya beberapa rumah sakit yang bekerjasama dengan BPJS. Kemudian sebagai jaminan kesehatan nasional, peserta BPJS berjumlah banyak, datang dari berbagai kalangan, baik pegawai negeri, swasta, bekerja maupun tidak, serta anggota keluarganya. Preminya yang murah juga menjadi daya tarik yang mengakibatkan antrian di rumah sakit tidak terhindarkan. Hal-hal tersebut sangat berbanding terbalik dengan pelayanan yang diberikan oleh asuransi swasta yang mengunggulkan kecepatan, kemudahan dan fleksibilitas. Sehingga bagi perusahaan yang sudah cukup mapan dan mampu serta ingin memberikan jaminan sosial yang lebih baik bagi tenaga kerjanya lebih memilih asuransi swasta.

Dengan begitu dapat dilihat bahwa implementasi kebijakan Pemerintah Daerah tentang Penyelenggaraan Ketenagakerjaan yang diwujudkan dalam bentuk Peraturan Daerah Nomor 8 Tahun 2015 tentang Penyelenggaraan ketenagakerjaan masih belum optimal karena masih banyak perusahaan atau dan tenaga kerja yang melanggarnya.

Kebijakan Publik menurut Dye (dalam Indiahono, 2009:17) adalah:

Whatever government choose to do or not to do. Maknanya Dye hendak menyatakan bahwa apapun kegiatan pemerintah baik yang eksplisit maupun implisit merupakan kebijakan. Interpretasi dari kebijakan menurut Dye diatas harus dimaknai dengan dua hal penting; pertama, bahwa kebijakan haruslah dilakukan oleh badan pemerintah, dan kedua, kebijakan tersebut mengandung pilihan dilakukan atau tidak dilakukan oleh pemerintah.

Sementara itu, menurut Anderson (dalam Agustina, 2012:7) mengatakan bahwa: "Kebijakan Publik adalah serangkaian kegiatan yang mempunyai maksud atau tujuan sekelompok aktor yang berhubungan dengan suatu permasalahan atau suatu hal yang diperhatikan".

Indikator yang memengaruhi implementasi menurut Van Meter dan Van Horn (dalam Indiahono, 2009: 38) sebagai berikut:

a) Sasaran dan tujuan kebijakan.

1) Ukuran tingkat keberhasilan 
2) Kejelasan tujuan.

b) Sumber daya.

1) Sumber daya manusia pendukung pelaksana kebijakan

2) Sumber daya dana sebagai pendukung pelaksana kebijakan

c) Komunikasi antar badan pelaksana.

1) Komunikasi antar pelaksana kebijakan.

2) Sosialisasi para pelaksana program kebijakan kepada masyarakat.

d) Karakteristik badan pelaksana.

1) Ketegasan para pelaksana kebijakan dalam pelaksanaan kebijakan.

2) Pengelolaan pendataan target sasaran kebijakan

e) Lingkungan sosial, ekonomi dan politik.

1) Kondisi ekonomi masyarakat pada saat pelaksanaan kebijakan.

2) Kondisi sosial target pada saat pelaksanaan kebijakan.

f) Sikap pelaksana.

1) Akuntabilitas para pelaksana didalam pelaksanaan kebijakan.

2) Responsibilitas para pelaksana kebijakan.

Dalam hal kebijakan, setiap peraturan yang bersifat wajib tentu selalu disertai dengan sanksi bagi yang melanggarnya. Dalam Peraturan Daerah tentang Penyelenggaraan Ketenagakerjaan di Kota Cimahi, didalamnya tidak tercantum mengenai sanksi yang diberikan kepada perusahaan yang melanggar kepesertaan BPJS tersebut. Dari hasil observasi awal, peneliti melihat bahwa pelaksana kebijakan dalam hal ini Pemerintah Kota Cimahi masih belum bertindak tegas dalam memberikan sanksi, hal ini dapat terlihat dari tidak tercantumnya sanksi dalam Peraturan Daerah tersebut sehingga perusahaan yang ada di Kota Cimahi tidak takut akan sanksi yang berlaku. Seharusnya sanksi tersebut juga dicantumkan dalam Peraturan Daerah terkait agar pelaksanaan kebijakan tersebut berjalan dengan optimal. Selain itu ketidak tegasan pemerintah dalam memberikan sanksi juga terlihat dari jumlah perusahaan yang tidak mendaftar BPJS dalam Tabel 2 yang tetap pada angka 123 perusahaan pada bulan Oktober sampai dengan bulan Desember. Hal tersebut dapat dikatakan bahwa perusahaan masih tidak jera akan sanksi yang berlaku sehingga masih enggan mendaftarkan dirinya dan tenaga kerjanya menjadi peserta BPJS. 
Berdasarkan pengamatan awal di atas, peneliti tertarik untuk melakukan penelitian mengenai "Kebijakan Pemerintah Daerah tentang Penyelenggaraan Ketenagakerjaan Dalam Program Badan Penyelenggara Jaminan Sosial BPJS di Kota Cimahi”.

\section{METODE PENELITIAN}

Penelitian ini adalah penelitian deskriptif dengan pendekatan kualitatif. Menurut (Sugiyono, 2013) penelitian kualitatif adalah meneliti pada kondisi obyek yang alamiah (sebagai lawannya adalah eksperimen), dimana peneliti adalah sebagai instrument kunci, teknik pengumpulan data dilakukan secara triangulasi (gabungan), analisis data bersifat induktif dan hasil penelitian kualitatif lebih menekankan makna dari pada generalisasi. Penelitian ini dilakukan di Dinas Tenaga Kerja Transmigrasi Dan Sosial Kota Cimahi.

Teknik pengumpulan data dalam penelitian ini adalah wawancara, observasi, dan dokumentasi. Wawancara yang dilakukan adalah wawancara terstruktur. Informan dalam penelitian ini adalah Kepala Dinas Tenaga Kerja, Transmigrasi dan Sosial Kota Cimahi, Aparatur Pemerintah di Kantor Dinas Tenaga Kerja Transmigrasi dan Sosial Kota Cimahi, Perwakilan perusahaan di kota Cimahi, Dewan Pengupahan Kota Cimahi, dan tenaga kerja. Sementara itu, teknik analisis data yang digunakan adalah reduksi data, penyajian data, dan penarikan kesimpulan. Kegita komponen tersebut berjalan Bersama pada waktu kegiatan pengumpulan data. Sedangkan dalam hal pengujian keabsahan data, peneliti menggunakan uji kredibilitas, nilai transfer penelitian, dan dependability.

\section{HASIL DAN PEMBAHASAN}

\section{Kebijakan Pemerintah Daerah tentang Penyelenggaraan Ketenagakerjaan dalam Program BPJS di Kota Cimahi}

Kebijakan dipandang sebagai tindakan untuk mencapai tujuan dan umumnya tujuan tersebut ingin dicapai oleh seseorang, kelompok ataupun pemerintah. Kebijakan pemerintah dibuat untuk mengatasi masalah yang 
ada dalam masyarakat. Masalah kebijakan bisa dilihat dari berapa banyak orang yang berpengaruh dalam suatu masalah tersebut. Hal tersebut muncul dari ketidakpuasan masyarakat terhadap kebijakan sebelumnya yang telah dibuat oleh pemerintah. Oleh karena itu, pemerintah merubah kebijakan yang telah dibuatnya atau membuat kebijakan baru untuk mengatasi berbagai permasalahan yang terjadi di masyarakat.

Adapun dimensi dan indikator yang digunakan penelitian untuk menjelaskan bagaimana implementasi kebijakan Pemerintah Daerah tentang Ketenagakerjaan khususnya dalam pemberian sosial bagi tenaga kerja di Kota Cimahi sebagai berikut:

\section{Ukuran dan Tujuan Kebijakan}

\section{Ukuran Keberhasilan Kebijakan}

Tolak ukur dari kebijakan tentang penyelenggaraan ketenagakerjaan dalam program BPJS dilihat dari presentase kepesertaan tenaga kerja dan perusahaan yang mendaftar BPJS. Kemudian, hasil penelitian di lapangan menunjukkan bahwa jumlah presentase kepesertaan BPJS, sebagai berikut:

Tabel 3

Presentase jumlah Kepesertaan BPJS

\begin{tabular}{|c|c|c|c|c|c|}
\hline \multirow[t]{2}{*}{ Bulan } & \multicolumn{2}{|c|}{$\begin{array}{l}\text { Perusahaan yang } \\
\text { mendaftar BPJS }\end{array}$} & $\begin{array}{l}\text { Perus } \\
\text { belum }\end{array}$ & $\begin{array}{r}\text { ahaan yang } \\
\text { mendaftar } \\
\text { BPJS }\end{array}$ & \multirow[t]{2}{*}{\begin{tabular}{|} 
Jumlah \\
Perusahaan
\end{tabular}} \\
\hline & Jumlah & Presentase & Jumlah & Presentase & \\
\hline Juli & 471 & $79.4 \%$ & 122 & $20,6 \%$ & 593 \\
\hline Agustus & 466 & $78,2 \%$ & 129 & $21,8 \%$ & 596 \\
\hline September & 477 & $78.7 \%$ & 129 & $21,3 \%$ & 606 \\
\hline Oktober & 468 & $79,2 \%$ & 123 & $20,8 \%$ & 591 \\
\hline November & 469 & $79,3 \%$ & 123 & $20,7 \%$ & 592 \\
\hline Desember & 470 & $79.2 \%$ & 123 & $20,8 \%$ & 593 \\
\hline
\end{tabular}




\begin{tabular}{|l|c|l|l|l|l|} 
& & & & & \\
\hline Rata-Rata & 470 & $79 \%$ & 125 & $21,0 \%$ & 595 \\
\hline
\end{tabular}

Sumber : Dinas Tenaga Kerja, Transmigrasi dan Sosial Kota Cimahi

Berdasarkan hasil wawancara dan data yang peneliti dapatkan, bahwa kebijakan tentang penyelenggaraan ketenagakerjaan dalam program BPJS di Kota Cimahi telah mempunyai tolak ukur yang jelas, karena untuk mengukur indikator keberhasilan implementasi kebijakan tentunya harus menegaskan standar dan sasaran tertentu yang harus dicapai oleh para pelaksana kebijakan. Kemudian jika dilihat dari banyaknya jumlah perusahaan yang mendaftar BPJS yakni telah mencapai presentase hingga $79 \%$, maka dengan begitu sudah dapat dikatakan bahwa kebijakan ini telah berhasil karena tingkat keberhasilan yang ditetapkan oleh pemerintah adalah $70 \%$, akan tetapi kebijakan ini belum berhasil sepenuhnya karena masih $21 \%$ dari jumlah perusahaan yang masih belum mendaftar BPJS sehingga pemerintah harus terus berupaya melakukan cara yang efektif yakni dengan terus melakukan sosialiasi dan menegakkan sanksi bagi tenaga kerja yang belum menjadi peserta BPJS agar ukuran keberhasilan kebijakan ini dapat tercapai sepenuhnya, dalam artian seluruh perusahaan dan tenaga kerja yang ada di Kota Cimahi menjadi peserta BPJS sehingga kebijakan yang telah dibuat oleh pemerintah tersebut dapat dilaksanakan dengan optimal.

Atas dasar hasil wawancara dan observasi yang peneliti lakukan maka peneliti menyimpulkan bahwa tolak ukur kebijakan mengenai penyelenggaraan ketenagakerjaan dalam program BPJS di Kota Cimahi sudah tercapai dengan baik karena telah melebihi presentase yang dijadikan tolak ukur keberhasilan kebijakan ini yakni perusahaan dan tenaga kerja yang menjadi peserta BPJS telah mencapai $79 \%$.

\section{Tujuan dari Kebijakan}

Berdasarkan hasil observasi peneliti terkait indikator tujuan kebijakan, menunjukkan bahwa kebijakan tentang penyelenggaraan ketenagakerjaan khususnya dalam pemberian jaminan sosial ini merupakan suatu upaya yang dilakukan oleh Pemerintah Daerah untuk mensejahterakan tenaga 
kerja di Kota Cimahi. Kemudian peneliti juga melihat bahwa pemahaman mengenai tujuan oleh para pelaksana kebijakan sudah cukup baik.

Pemerintah sebagai pelaksana kebijakan tentang penyelenggaraan ketenagakerjaan ini sudah memahami tujuan dari kebijakan itu sendiri. Dalam indikator tujuan kebijakan, pemahaman dari pelaksana kebijakan tersebut sangat penting karena hal tersebut sangat mempengaruhi pelaksanaan kebijakan. Jika pelaksana kebijakan tidak mengetahui maksud dan tujuan dari dibuatnya kebijakan tersebut maka mereka tidak akan mengetahui apa yang harus dilakukannya untuk mencapai tujuan tersebut. Implementasi kebijakan akan gagal dilaksanakan apabila implementor tidak memahami tujuan dari kebijakan yang akan dilaksanakannya sehingga setelah pemerintah sebagai pelaksana kebijakan telah memahami tujuan dari kebijakan tersebut, selanjutnya pemerintah tinggal menentukan cara yang efektif untuk mencapai tujuan tersebut. Dengan begitu, implementasi kebijakan dapat dilaksanakan dengan optimal.

Atas dasar wawancara dan observasi yang dilakukan oleh peneliti, maka dapat dikatakan bahwa tujuan dari kebijakan tentang penyelenggaraan ketenagakerjaan di Kota Cimahi sudah cukup jelas yakni untuk mensejahterakan tenaga kerja di Kota Cimahi dan apabila melihat hasil dari kebijakan yang dirasakan oleh tenaga kerja mengenai jaminan sosial yang diberikan oleh pemerintah, maka dapat dikatakan bahwa tujuan dari kebijakan tentang pemberian jaminan sosial sudah tercapai.

\section{Sumber Daya}

\section{Sumber Daya Manusia}

Dari hasil observasi peneliti di Dinas Tenaga Kerja, Transmigrasi dan Sosial mengenai sumber daya manusia seperti apa yang dibutuhkan dalam pelaksanaan kebijakan tentang penyelenggaraan ketenagakerjaan dalam program BPJS, kemudian sumber daya yang seperti apa yang dapat dikatakan berkualitas dan apakah kuantitas yang tersedia dan sudah sesuai dengan yang dibutuhkan dalam pelaksanaan kebijakan ini.

Dari hasil wawancara dan observasi yang telah dilakukan oleh peneliti, bahwa apabila berbicara mengenai indikator sumber daya manusia, dapat 
dilihat dari dua aspek yakni kualitas dan kuantitas. Sumber daya manusia sebagai pelaksana kebijakan Pemerintah Daerah tentang penyelenggaraan ketenagakerjaan di Kota Cimahi sudah cukup berkualitas karena tingkat pendidikan dan pengamalaman kerja yang sangat mempengaruhi kualitas sumber daya manusianya telah sesuai dengan yang dibutuhkan. Tingkat pendidikan yang tinggi membuat sumber saya manusia mempunyai pengetahuan yang tinggi pula karena melalui pendidikan yang ditempuhnya, ilmu yang didapatkan semakin luas. Sehingga dalam menjalankan pekerjaanya sumber daya manusia yang berpendidikan tinggi harus bisa memanfaatkan ilmu yang didapatnya dengan maksimal agar tujuan yang diinginkannya dapat tercapai dengan optimal. Peneliti melihat sumber daya yang ada di Dinas Tenaga Kerja, Transmigrasi dan Sosial rata-rata pegawainya telah menempuh jenjang pendidikan yang tinggi.

\section{Sumber Daya Finansial}

Berdasarkan wawancara, bahwa setiap indikator sumber daya finansial merupakan hal yang paling penting yang harus ada di dalam pemerintahan. Karena sumber daya finansial merupakan alat yang dibutuhkan oleh organisasi publik untuk menyelenggarakan kegiatan pemerintahan. Oleh karena itu, pemerintah menyusun suatu anggaran agar alur pendapatan dan pengeluaran yang didapat dan digunakan untuk penyelenggaraan pemerintahan tersusun rapih dan dapat dijadikan acuan untuk penyelenggaraan pemerintahan. Setiap Satuan Kerja Perangkat Daerah (SKPD) membuat Rancangan Kegiatan dan Anggaran (RKA) yang merupakan dokumen perencanaan dan penganggaran yang berisi program dan kegiatan SKPD serta anggaran yang diperlukan untuk melaksanakan kegiatan yang akan dilakukan oleh setiap SKPD yang nantinya dituangkan ke dalam APBD untuk penyelenggaraan pemerintahan di tingkat daerah termasuk dalam penyelenggaraan ketenagakerjaan oleh Dinas Tenaga Kerja, Transmigrasi dan Sosial Kota Cimahi. Oleh karena itu anggaran tersebut diajukan oleh Dinas Tenaga Kerja, Transmigrasi dan Sosial itu sendiri dan atas pertimbanganpertimbangan yang matang untuk menyelenggarakan pemberian jaminan sosial bagi tenaga kerja 


\section{Komunikasi Antar Badan Pelaksana}

\section{Koordinasi Antar Pelaksana Kebijakan}

Atas dasar wawancara dan observasi, peneliti melihat bahwa indikator koordinasi antar badan pelaksana merupakan usaha yang sejalan antara satu pihak dengan pihak lainnya untuk menghasilkan suatu tindakan yang seragam. Jadi, koordinasi diperlukan agar tindakan yang akan dilaksanakan oleh beberapa pihak dapat berjalan dengan seragam dan harmonis agar sasaran yang telah ditentukan dapat tercapai. Antara kedua instansi tersebut dirasa sudah cukup baik karena dalam penyelenggaraan pelayanannya tidak ada tenaga kerja yang merasa dirugikan akibat koordinasi antara para pelaksana kebijakan. Oleh karena itu dapat dikatakan bahwa koordinasi antar badan pelaksana kebijakan ini telah terjalin dengan baik.

\section{Sosialisasi}

Berdasarkan hasil obeservasi peneliti terkait sosialisasi kebijakan menunjukkan bahwa sosialisasi mengenai kebijakan tentang jaminan sosial ini telah sebelumnya dilakukan oleh Pemerintah Pusat sebelum dilaksanakan di tingkat daerah yakni melalui media elektronik dengan memasang iklan di televisi, menyebar pamflet serta melalui media sosial, sehingga Pemerintah Daerah cukup meneruskan informasi tersebut secara langsung kepada para pengusaha dan tenaga kerja yang ada di Kota Cimahi.

Indikator sosialisasi merupakan suatu kegiatan yang dilakukan agar seseorang mendapatkan pengetahuan dari apa yang sebelumnya tidak diketahui. Dengan adanya sosialisasi seseorang mendapatkan pengetahuan sehingga menimbulkan keinginan untuk berpartisipasi dalam lingkungan masyarakat. Dalam penyelenggaraan kebijakan tentang penyelenggaraan ketenagakerjaan dalam program BPJS, pemerintah yang sangat berperan aktif dalam mensosialisasikan kebijakan ini karena memang pemerintah yang mempunyai tanggung jawab penuh sebagai pelaksana kebijakan. Sosialisasi yang dilakukan pemerintah sudah cukup baik dan jelas karena pemerintah memberikan pengetahuan kepada target sasaran kebijakan ini 
yaitu tenaga kerja dan perusahaan yang ada di Kota Cimahi agar dapat berpartisipasi dalam pelaksanaan kebijakan ini. Tentunya hal tersebut perlu disertai dukungan dari pemberi pelayanan itu sendiri yakni pihak BPJS yang masih memberikan pelayanan yang buruk seperti salah satunya adalah penolakan dari pihak rumah sakit terhadap peserta BPJS. Seharusnya pihak BPJS memperbaiki koordinasi dengan rumah sakit agar tidak ada penolakan terhadap pasien yang menggunakan BPJS. Hal tersebut dirasa wajar apabila masih ada perusahaan yang enggan menjadi peserta BPJS dan memilih asuransi kesehatan swasta. Atas dasar hasil wawancara dan observasi yang peneliti lakukan, maka peneliti menyimpulkan bahwa sosialisasi yang telah dilakukan oleh pemerintah sudah cukup optimal, hal tersebut juga terlihat dari pengetahuan tenaga kerja itu sendiri bahwa menjadi peserta BPJS itu adalah kewajiban.

\section{Karakteristik Badan Pelaksana}

\section{Ketegasan Para Pelaksana Kebijakan dalam Pelaksanaan Kebijakan}

Indikator ketegasan dari pada para pelaksana kebijakan memiliki tingkat kesulitan yang berbeda-beda dalam proses implementasinya terutama dalam disposisi atau sikap dari pelaksana kebijakan dimana jika suatu pelaksanaan kebijakan ingin efektif maka para pelaksana kebijakan tidak hanya harus mengetahui apa yang akan dilakukan tetapi juga memiliki kemampuannya untuk melaksanakannya. Jika dikaitkan dengan hal tersebut, dalam hal ini pemerintah memahami apa yang harus dilakukan terhadap perusahaan yang tidak menjadi peserta BPJS yakni dengan memberikan sanksi berupa teguran tertulis sebanyak dua kali dan diberikan jangka waktu selama 10 hari untuk segera mendaftarkan tenaga kerjanya menjadi peserta BPJS, apabila setelah diberikan teguran tersebut perusahaan masih saja tidak mendaftar BPJS, maka diberikan sanksi denda sebesar $0.1 \%$ dari iuran yang seharusnya dibayar yang dihitung sejak teguran tertulis kedua berakhir. Apabila setelah denda tersebut diberlakukan dan tidak disetor lunas, maka sanksi selanjutnya adalah tidak diberikan pelayanan terkait perizinan seperti IMB (Izin Mendirikan Bangunan), Izin memperkerjakan tenaga kerja Asing dan sebagainya. 


\section{Pengelolaan Pendataan Target Sasaran}

Pengelolaan pendataan tenaga kerja oleh para pelaksana kebijakan terhadap target sasaran kebijakan terkait implementasi kebijakan Pemerintah Daerah tentang penyelenggaraan ketenagakerjaan sudah cukup baik.

Berdasarkan observasi yang dilakukan oleh peneliti menunjukkan bahwa pengelolaan pendataan target sasaran oleh pelaksana kebijakan yakni pemerintah sudah cukup baik. Peneliti juga merasakan sendiri dilihat dari data-data yang didapat dari Dinas Tenaga Kerja, Transmigrasi dan Sosial yang sangat lengkap, seperti pada gambar berikut:

\section{Gambar 1}

Pendataan Dinas Tenaga Kerja, Transmigrasi dan Sosial

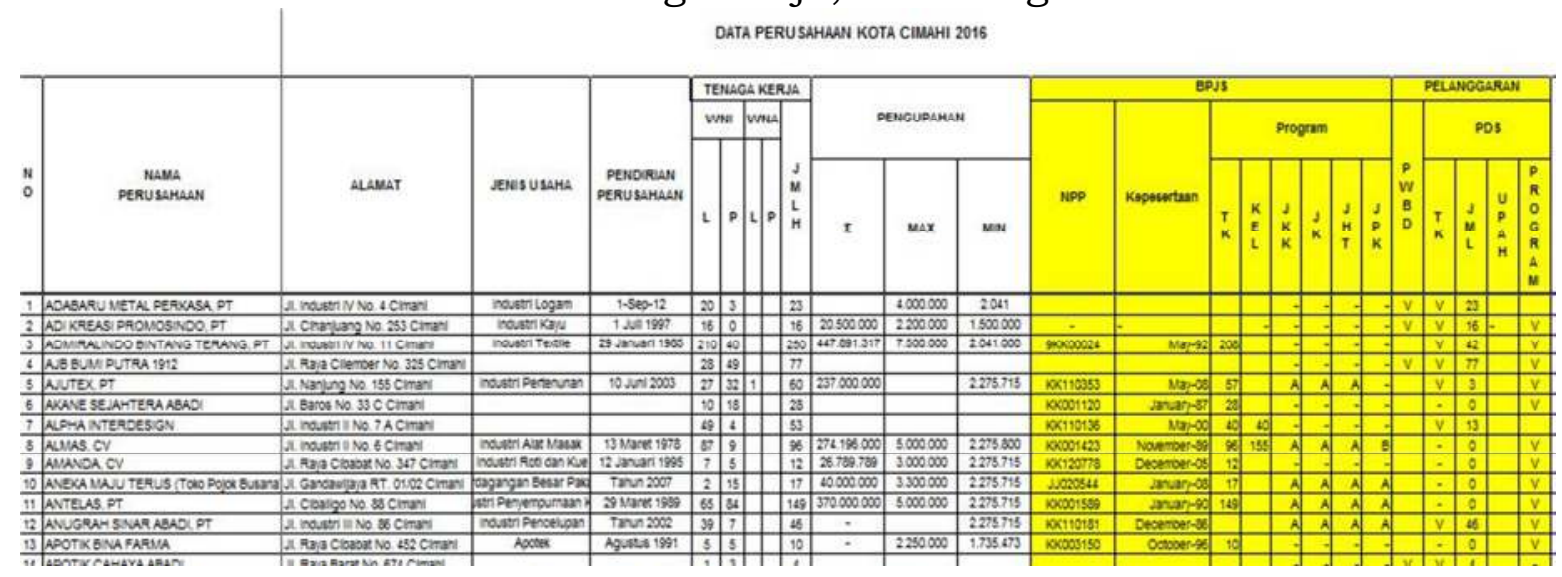

Sumber: Dokumen Dinas Tenaga Kerja, Transmigrasi dan Sosial Kota Cimahi 2016

Gambar 1 menujukkan data-data mengenai ketenagakerjaan mulai dari nama perusahaan, alamat perusahaan, tanggal berdirinya perusahaan, jumlah tenaga kerja, jumlah upah, hingga program jaminan sosial. Dalam indikator pengelolaan pendataan, kelengkapan data tersebut membantu pemerintah untuk membuat suatu keputusan dan mengevaluasi kebijakan yang telah diimplementasikan misalnya masih banyaknya perusahaan yang tidak mendaftar BPJS, maka pemerintah perlu melakukan sebuah tindakan atau strategi agar seluruh perusahaan dan tenaga kerja di Kota Cimahi menjadi peserta BPJS. Sehingga dalam implementasi kebijakan yang selanjutnya dapat berjalan lebih optimal. 


\section{Lingkungan Sosial, Ekonomi, dan Politik}

\section{Kondisi Ekonomi Masyarakat pada saat Pelaksanaan Kebijakan}

Berdasarkan hasil observasi yang dilakukan oleh peneleliti, bahwa kondisi ekonomi dari target sasaran kebijakan tentang ketenagakerjaan terutama dalam hal pemberian jaminan sosial ini sudah cukup baik. Pasalnya, Upah Minimum Kota (UMK) Kota Cimahi pada tahun 2017 yang diterima oleh tenaga kerja sudah mencapai Rp.2.463.461. Angka tersebut sudah dapat dikatakan besar jika dibandingkan dengan kota-kota kecil di Jawa Barat.

Berdasarkan wawancara dan observasi yang dilakukan oleh peneliti, bahwa apabila melihat upah yang diterima oleh tenaga kerja yang sesuai dengan UMK dan dikaitkan dengan adanya kebijakan tentang pemberian jaminan sosial oleh pemerintah ini dapat dikatakan bahwa kebijakan ini cukup membantu meminimalisir kebutuhan-kebutuhan tenaga kerja karena tenaga kerja dapat merasakan manfaat secara langsung yang didapatkan khususnya apabila mengikuti program BPJS Ketenagakerjaan yang dimana setiap iuran per bulanya bisa dicairkan sehingga bisa membantu untuk memenuhi kebutuhan hidupnya. Dalam indikator kondisi ekonomi, setiap kebijakan yang dibuat oleh Pemerintah harus menyesuaikan dengan kondisi ekonomi dari target sasaran kebijakan agar kebijakan tersebut dapat diterima oleh target sasaran dan dapat membantu mengubah kondisi ekonomi target sasaran menjadi lebih baik. Oleh karena itu, dapat dikatakan bahwa kebijakan tentang penyelenggaraan ketenagakerjaan khususnya dalam hal pemberian jaminan sosial ini sudah sesuai dengan kondisi ekonomi tenaga kerja di Kota Cimahi.

\section{Kondisi Sosial Target pada saat Pelaksanaan Kebijakan}

Berdasarkan observasi yang dilakukan oleh peneliti bahwa kondisi sosial tenaga kerja pada saat kebijakan ini dilaksakan berada dalam tahap membutuhkan jaminan, karena pada saat ini mayoritas perindustrian di Kota Cimahi adalah jenis industri garment dan textile yang menggunakan mesin-mesin yang sudah cukup canggih sehingga kecelakaan kerja rawan terjadi. Oleh karena itu pemerintah membuat jaminan sosial bagi tenaga 
kerja untuk melindungi tenaga kerja baik saat sedang bekerja maupun setelah tidak bekerja.

Dalam indikator kondisi sosial, setiap kebijakan yang dibuat oleh pemerintah harus sesuai dengan kondisi sosial masyarakatnya begitupula dengan kebijakan tentang penyelenggaraan ketenagakerjaan dalam program BPJS di Kota Cimahi ini yang mempunyai prinsip gotong royong yakni prinsip kebersamaan antar peserta dalam menanggung beban biaya jaminan sosial yang diwujudkan dengan kewajiban setiap peserta membayar iuran sesuai dengan tingakat gaji, upah atau tingkat penghasilannya. Artinya, setiap iuran yang dibayarkan oleh perusahaan dan tenaga kerja, disalurkan untuk orang-orang yang saat ini sedang membutuhkan. Iuran BPJS tersebut tidak selalu dirasakan manfaatnya secara langsung, karena tidak setiap bulan ada tenaga kerja yang sakit atau mengalami kecelakaan kerja sehingga iuran yang terkumpul di BPJS digunakan untuk membiayai tenaga kerja yang lain. Prinsip gotong royong ini sesungguhnya sudah menjadi salah satu prinsip dalam hidup bermasyarakat dan juga merupakan salah satu akar dalam kebudayaan Indonesia. Dalam hal ini prinsip gotong royong berarti peserta yang mampu membantu peserta yang kurang mampu, peserta yang sehat membantu yang sakit atau yang berisiko tinggi. Hal ini terwujud karena kepesertaan BPJS ini bersifat wajib untuk seluruh penduduk, tanpa pandang bulu. Dengan demikian, melalui prinsip gotong royong jaminan sosial dapat menumbuhkan keadilan sosial bagi seluruh rakyat Indonesia.

\section{Sikap Pelaksana}

\section{Akuntabilitas para Pelaksana dalam Pelaksanaan Kebijakan}

Berdasarkan uraian wawancara yang dilakukan oleh peneliti, bahwa dalam indikator akuntabilitas badan pelaksana, setiap kebijakan yang dibuat oleh pemerintah perlu mempertimbangkan segala sesuatunya agar tidak ada pihak-pihak yang merasa dirugikan. Terkadang kebijakan dibuat hanya karena keinginan pemerintah itu sendiri tanpa memperhatikan keinginan masyarakat dan pihak-pihak lain sebagai pendukung kebijakan. Seperti halnya dalam kebijakan tentang penyelenggaraan ketenagakerjaan dalam program BPJS. Kebijakan ini hanya dibuat untuk mensejahterakan tenaga 
kerja tanpa memperhatikan perusahaan sebagai perantara dari kebijakan tersebut. Peneliti melihat bahwa dalam pelaksanaan kebijakan ini pemerintah seperti melepaskan tanggung jawab dan menyerahkan tanggung jawabnya kepada perusahaan. Dan demi terselenggaranya proses penjaminan sosial bagi tenaga kerja dan demi mencapai kesejahteraan tenaga kerja, pemerintah terkesan memaksakan pihak-pihak sebagai target perantara kebijakan ini untuk mendukung pelaksanaan kebijakan yang telah dibuat oleh pemerintah tanpa mempertimbangkan segala sesuatunya. Seharusnya pemerintah dalam membuat sebuah kebijakan perlu mempertimbangkan pihak-pihak yang mendukung pelaksaan kebijakan sehingga tidak ada pihak yang merasa terbebani. Oleh karena itu, peneliti menyimpulkan bahwa akuntabilitas pelaksana kebijakan ini dapat dikatakan kurang baik.

\section{Responsibilitas para Pelaksana Kebijakan}

Responsibilitas implementor terhadap kebijakan berkaitan dengan kemauan implementor untuk melaksanakan kebijakan publik. Ada kebijakan yang dilaksanakan secara efektif karena mendapat dukungan dari para pelaksana kebijakan, akan tetapi kebijakan-kebijakan lain mungkin akan bertentangan secara langsung dengan pandangan-pandangan pelaksana kebijakan atau kepentingan kepentingan pribadi atau organisasi dari para pelaksana. Jika suatu pihak diminta untuk melaksanakan perintah-perintah yang tidak mereka setujui, maka kesalahan-kesalahan yang tidak diinginkan akan terjadi. Berdasarkan wawancara yang dilakukan oleh peneliti, bahwa dalam indikator responsibilitas, pada saat pemerintah membuat suatu kebijakan, pemerintah harus melaksanakan proses kebijakan seutuhnya mulai dari formulasi, implementasi hingga evaluasi kebijakan terutama dalam hal implementasinya, karena implementasi merupakan tahapan yang penting dalam keseluruhan struktur kebijakan. Pemerintah tidak hanya harus melakukan sosialisasi kebijakan saja tetapi juga harus bersikap responsif dan terus mengawasi implementasi kebijakan yang telah dibuatnya untuk melihat sejauhmana keberhasilan dari kebijakan tersebut. 


\section{KESIMPULAN}

Setelah peneliti melakukan penelitian di lapangan didapatlah hasil bahwa implementasi kebijakan pemerintah tentang penyelenggaraan ketenagakerjaan di Kota Cimahi dalam program BPJS masih belum sesuai harapan. Hal ini terlihat dari:

1. Ukuran dan tujuan kebijakan. Setelah dilakukan penelitian, bahwa ukuran dan tujuan dari kebijakan tentang penyelenggaraan ketenagakerjaan di Kota Cimahi sudah cukup baik karena ukuran keberhasilan kebijakan sudah tercapai dengan baik karena telah melebihi presentase yang dijadikan tolak ukur keberhasilan kebijakan ini yakni perusahaan dan tenaga kerja yang menjadi peserta BPJS telah mencapai $79 \%$ serta tujuan dari kebijakan tentang pemberian jaminan sosial sudah tercapai.

2. Sumber Daya. Sumber daaya yang mendukung implementasi kebijakan tentang penyelenggaraan ketenagakerjaan di Kota Cimahi sudah cukup baik. Hal ini terlihat dari sumber daya manusia sebagai pelaksana kebijakan tentang penyelenggaraan ketenagakerjaan khususnya dalam hal pemberian sosial bagi tenaga kerja di Kota Cimahi cukup baik, kemudian dari segi sumber daya finansial sudah mencukupi karena sudah ada anggaran tersendiri yang tercantum dalam APBD.

3. Komunikasi Antar Badan Pelaksana. Komunikasi antar badan pelaksana sudah cukup baik, hal ini ditandai dengan sudah adanya koordinasi yang baik antar pelaksana kebijakan dan sosialisasi yang dilakukan oleh para pelaksana kebijakan terhadap perusahaan dan tenaga kerja telah dilaksanakan dengan baik.

4. Karakteristik Badan Pelaksana. Karakteristik Badan Pelaksana sudah cukup baik karena pemerintah sudah cukup tegas dalam melaksanakan kebijakan tentang pemberian jaminan sosial ini, hanya saja seharusnya sanksi tersebut dicantumkan dalam Peraturan Daerah tentang Penyelenggaraan Ketenagakerjaan agar lebih jelas dan efektif dalam pelaksanaannya dan dalam pengelolaan pendataan target kebijakan sudah cukup baik

5. Kondisi Sosial, Ekonomi dan Politik. Kebijakan tentang penyelenggaraan ketenagakerjaan di Kota Cimahi khususnya dalam pemberian jaminan sosial sudah sesuai dengan kondisi sosial ekonomi tenaga kerja saat ini karena 
kebijakan ini cukup membantu tenaga kerja dalam kehidupan ekonomi dan sosialnya.

6. Sikap Pelaksana. Sikap pelaksana kebijakan masih kurang baik karena pemerintah masih kurang bertanggung jawab dan kurang responsif terhadap pengusaha yang merupakan salah satu sasaran yang merasa terbebani dengan adanya kebijakan tentang penyelenggaraan ketenagakerjaan di Kota Cimahi khususnya dalam pemberian jaminan sosial ini.

\section{DAFTAR PUSTAKA Buku}

Agustino, Leo. 2006. Dasar-Dasar Kebijakan Publik (edisi revisi). Bandung: Alfabeta.

Agustino, Leo. 2006. Dasar-Dasar Kebijakan Publik. Bandung: Alfabeta Bungin, Burhan. 2001. Metodelogi Penelitian Kualitatif.Jakarta: PT Raja Grapindo Persada

Budiarjo, Miriam. 2008. Dasar-Dasar Ilmu Politik. Jakarta: PT Gramedia Pustaka Utama

Indiahono, Dwiyanto. 2009. Kebijakan Publik Berbasis Dynamic Policy Analisys. Yogjakarta: Gava Media.

Moleong, Lexy J. (2005). Metode Penelitian Kualitatif. Bandung: PT Remaja Rosdakarya.

Nasution, S. (1996). Metode Penelitian Naturalistik-Kualitatif. Bandung : Tarsito Ndraha Taliziduhu, 2003. Kybernology (Ilmu Pemerintahan Baru) 2. Jakarta: Rineka Cipta.

Nugroho Riant, 2014. Public Policy. Jakarta: PT Elex Media Komputindo.

Partanto, Pius dkk. 2001. Kamus Ilmiah Popular. Surabaya: Arkola.

Sugiyono, 2012. Metode Penelitian Administrasi. Bandung: Alfabeta.

Sugiyono.2014. Metode Penelitian Pendidikan-Pendekatan Kuantitatif, Kualitatif, dan $R \& D$. Bandung: Alfabeta.

Syaukani, dkk. 2012. Otonomi Daerah Dalam Negara Kesatuan. Yogyakarta: Pustaka Pelajar.

\section{Jurnal Penelitian}

Indra, Muhammad Andityaputra, Budhi Wibhawa, \& MuhammadFedryansyah. 2013. Implementasi Kebijakan Ketenagakerjaan Di Kabupaten Sumedang. Universitas Padjajaran. Diambil dari http://fisip.unpad.ac.id/jurnal/index.php/prosiding/article/download/143/ 128 (6 Januari 2017)

Rahmad, Aditya Pratama, 2016. Implementasi Kebijakan Dinas Sosial Dan Tenaga Kerja Dalam Menanggulangi Pengangguran Di Kota Tanjungpinang. Universitas Maritim Raja Ali Haji Tanjungpinang. Diambildari: http:/ /jurnal.umrah.ac.id/wp-content/uploads/gravity_forms / 1ec61c9cb232a03a96d0947c6478e525e/2016/08/e-journal-word.pdf Januari 2017) 


\section{Dokumen Dan Peraturan Perundang-Undangan}

Republik Indonesia Nomor 9 Tahun 2001 Tentang Pembentukan Kota Cimahi Republik Indonesia Nomor 13 Tahun 2003 Tentang Ketenagakerjaan

Republik Indonesia Nomor 24 Tahun 2011 Tentang Badan Penyelenggara Jaminan Sosial

Republik Indonesia Nomor 23 Tahun 2014 Tentang Pemerintahan Daerah

Peraturan Pemerintah Nomor 29 Tahun 1975 Tentang Pembentukan Kota Administratif Cimahi

Peraturan Pemerintah Republik Indonesia Nomor 86 Tahun 2013 Tentang Tata Cara Pengenaan Sanksi Administratif Kepada Pemberi Kerja Selain Penyelenggara Negara Dan Setiap Orang, Selain Pemberi Kerja, Pekerja, Dan Penerima Bantuan Iuran Dalam Penyelenggaraan Jaminan Sosial.

Peraturan Perundang-undangan Nomor 1 tahun 2003 tentang Kewenangan Kota Cimahi sebagai Daerah Otonom.

Peraturan Daerah Kota Cimahi Nomor 8 Tahun 2015 Tentang Penyelenggaraan Ketengakerjaan 